УДК 1(430)«17/18» $(075,8)$

DOI https://doi.org/10.32837/apfs.v0i32.1034

Т.Г.Румяниева

ORCID ID: https://orcid.org/0000-0001-5893-9852

доктор философских наук, профессор

Белорусского государственного университета

\title{
О ТАК НАЗЫВАЕМОЙ «ГЕНЕАЛОГИЧЕСКОЙ ПРЕЕМСТВЕННОСТИ» В РАЗВИТИИ НЕМЕЦКОГО КЛАССИЧЕСКОГО ИДЕАЛИЗМА
}

Сравнительный анализ наиболее знаковых проектов немецкого идеализма, разработанных И. Кантом и его ближайшими последователями в лице И. Фихте, Ф. Шеллинга и Г. Гегеля, позволяет сделать вывод, что великого кенигсбержца не следует, как это традиционно считалось, рассматривать в качестве непосредственного предтечи и основоположника данной классической традиции. Более того, вряд ли можно говорить о нем как о философе, заложившем основы той исторической формы диалектики, с которой обычно ассоциируется немецкая классика, особенно в гегелевской ее редакции. Такого рода идеи нередко звучат и в ряде историко-философских работ последних десятилетий [3;6].

Это вовсе не означает, что все выше названные последователи Канта не опирались при создании своих философских систем на ряд выдвинутых именно им фундаментальных положений. Не случайно его ближайший последователь Фихте не без оснований писал: «Я всегда говорил и повторяю здесь, что моя система - не что иное, как система Канта, т.е. она содержит тот же взгляд на предмет» $[9$, с. 446$]$. Он также называл свое наукоучение единственно правильно понятой философией Канта, «единственно возможной формой, превратившей критическую философию трансцендентального идеализма в единый слиток, систематизированный и вместе с тем более понятный». Хотя не следует забывать и о том, что, посвящая свою жизнь, как он писал, «изложению великого открытия Канта», Фихте в то же самое время отмечал, что тому «совершенно не удалось его предприятие», что «в своем способе изложения он совершенно не зависит от Канта» и, более того, что его «сочинения хотят не объяснять Канта; <...> они должны стоять сами по себе», а сам он стремится «К полной переработке его (Канта - Т.P.) образа мыслей» [9, с. 446-447].

Что касается Шеллинга, то и он, прежде чем осознать собственную миссию в философии, с одной стороны, целиком и полностью находился под влиянием идей своего непосредственного предшественника в лице Фихте и приступил к разработке собственной системы во многом изнутри фихтеанского наукоучения, а с другой - разработав основные принципы натурфилософии, он резко выступит против идей своего непосредственного предшественника, заявив, что его наукоучение не может быть использовано в качестве эталона. Он создаст свою версию трансцендентального идеализма, радикально отличающуюся от ограниченного субъективного идеализма Фихте, предложив «идеализм во всей его полноте и доказательности <...> как непрерывную историю самосознания" [10, с. 228]. Хотя нельзя не отметить, что его работы, особенно ранние, стали своего рода связующим звеном между идеями Канта, Фихте, с одной стороны, и Гегеля - с другой, демонстрируя и в самом деле определенного рода преемственность в развитии немецкого идеализма второй половины XVIII - первой трети XIX вв.

Именно в таком ключе, акцентируя на «прямой генеалогической преемственности", в советской историко-философской литературе, включая и учебные пособия, в течение долгих лет и воспроизводилось представление о единстве и цельности, наличии имманентной логики в развитии систем главных представителей данной философской традиции. При этом полагалось, что всем ее представителям присуще единое проблемное поле, сходное понимание основных идей, понятий и т.п. Не скрою, автор данной статьи сама не раз использовала эту схему, опираясь тогда на исследования известных советских авторов [5]. Однако знакомство с новейшими научными разработками и архивными данными последних десятилетий во многом изменили образ немецкой классической философии. Это позволяет нам утверждать об избыточной упрощенности такого рода схемы, ее неполном соответствии реальному положению дел. В исследованиях современных авторов немецкий идеализм предстает, скорее, «в пестром многообразии конкурирующих версий развертывания философского дискурса, от дедуктивного «геометрического метода" до изощренных герменевтических штудий, во всем богатстве литературных жанров, от сухого трактата до эпического визионерского повествования, в единстве осуществленного и неосуществленного». Более того, наследие немецкой философии этого периода рассматривают сегодня и как «состоящее из множества текстов разной степени законченности и самостоятельности...», и как больше похожее «на недостроенное 
здание, покрытое лесами и со всех сторон окруженное заготовленными строительными блоками, причем о назначении некоторых из них сегодня можно только гадать» [7, с. 209-210].

В статье предпринята попытка показать не только упрощенный характер выше отмеченного образа немецкой классики, но и его идеологическую ангажированность. Речь идет, в частности, о предложенной в свое время Ф. Энгельсом схеме развития немецкой классической философии, которая долгие годы господствовала в советской историко-философской и учебной литературе. Согласно этой схеме, каждый следующий за Кантом ее представитель позиционировался как превосходящий предшественника по своим результатам, а все догегелевские системы часто рассматривались не более как подготовка к созданию вначале гегелевской, а затем и марксистской философии. Более того, в немецкую классическую философию Энгельс включил не только идеалистические системы Канта, Фихте, Шеллинга и Гегеля, но и материализм Фейербаха, который, по словам классика марксизма, существенно превзошел своих предшественников, став своего рода «посредствующим звеном» между философией Гегеля и учением Маркса [11].

Но вернемся к Канту. Для аргументации тезиса о том, что, несмотря на приверженность со стороны Фихте, Шеллинга и в гораздо меньшей степени Гегеля общих с Кантом и довольно существенных принципов, кенигсбергского философа все же нельзя ставить с ними в один ряд. 0 преемственности здесь можно говорить лишь с очень большими натяжками, так как Кант разработал и придерживался на протяжении всей своей жизни совершенно особой версии идеализма, в принципе отличающейся от той, которую развивали его последователи. Сам философ, кстати говоря, не раз открещивался от идей Фихте. Так, в своем «Заявлении по поводу наукоучения Фихте» от 7 августа 1799 г. в ответ на предложение рецензента «Очерка трансцендентальной философии Буле» в Эрлангенской литературной газете он писал, что «считает наукоучение Фихте совершенно несостоятельной системой. Ибо чистое наукоучение представляет собой только логику, которая со своими принципами не достигает материального момента познания и как чистая логика отвлекается от его содержания. Попытка выковырять из нее реальный объект представляет собой напрасный и потому никогда не выполнимый труд...Сказанного достаточно, чтобы отмежеваться от любого участия в этой философии» [4, с. 625].

Трансцендентальный идеализм Канта и в самом деле существенно отличался от взглядов вышеперечисленных его последователей. Так, главной целью философа, как известно, была реформа метафизики, превращение ее в подлинную науку, которая бы благодаря этой реформе достигла бы той же степени достоверности, что и математика с естествознанием. Из дисциплины о вещах сверхчувственного мира она была превращена им в науку априорного синтетического познания о природе и нравах, отвечая на вопрос о том, что мы можем знать и как мы можем знать путем изучения способа работы нашего ума.

Однако этот проект был впоследствии радикально отвергнут его последователями, начиная уже с Фихте, который и осуществил своего рода "перерождение метафизики" на диалектической основе» [6, с. 178]. Поэтому «сегодня влияние Канта уже никак не связано с учениями, которые создавались под впечатлением от его системы в конце XVIII в.» [3, с. 427]. Хотя это не означает, что мы должны полностью отрывать начатую Кантом философскую традицию, названную «немецким классическим идеализмом» как совокупность учений Канта, Фихте, Шеллинга и Гегеля.

Кантовская реформа предшествующей метафизики и в самом деле привела к радикальному разрыву со всеми ее схоластическими версиями и к ориентации философии на опыт и науку. Если же мы обратимся к учениям его последователей, то сразу же заметим, что они отдают приоритет интуитивному, сверхопытному познанию - интеллектуальной интуиции (Фихте, Шеллинг). Это особенно заметно, когда мы начинаем сравнивать кантовскую трактовку трансцендентального единства апперцепции с фихтевским $Я$, из которого он выводит не только форму, но и все содержание сущего, отрицая кантовское представление о действующих в неразрывном единстве двух способностях нашего познания - чувственности и рассудке. Сам разум, понимаемый Кантом только как одна из человеческих познавательных способностей, хотя и высшая, возводится его последователями в ранг субстанциальной основы мира. В соответствие с этим мы имеем, начиная уже с Фихте, дело с принципиально иной разновидностью идеализма. Так, придерживаясь собственной версии трансцендентально-критического идеализма, Кант признавал объективное существование мира вне нас, а также вещей в себе, аффицирующих нашу чувственность, познавательную ценность опытного познания. Что же касается его последователей, то они разрабатывают чистого вида идеализм, т.н. «подлинный», который начинается с фихтеанского устранения вещи в себе в ее кантовском значении. Кант полагал, что мы не создаем вещи, что они всегда даны нам в чувственном восприятии; от нашей же познавательной способности зависит только то, как они нам даны и как предметы нам являются. В этом смысле предмет познания должен с необходимостью подчиняться априорным формам нашего сознания как условиям возможности опыта. Он и считал, что, изучив эти всеобщие формы, мы сможем составить 
представление и о самом предмете опыта. Но речь у него идет только о форме нашего познания предмета, а не о его содержании. Так что в свете выше изложенного вряд ли представляется возможным говорить о прямой «генеалогической преемственности» в развитии немецкого идеализма от Канта к Фихте и т.д. Тем более, когда речь заходит о Гегеле, который, начиная с ранних своих работ, резко критиковал и Шеллинга (с критического разбора его Абсолюта фактически и развертывается все изложение «Феноменологии духа»), и кантовскую вещь в себе, и его учение о морали, и его версию диалектики, к который мы и переходим.

Так, трансцендентальная диалектика Канта, нашедшая свое наиболее полное выражение в его "Антиномике чистого разума», не может быть принята в качестве источника как гегелевской, так и марксистской теории развития. Вспомним, что сам Кант придавал ей исключительно негативное значение, характеризуя ее как «логику иллюзий», или «логику видимости». В данном разделе его первой «Критики» можно найти множество, мягко выражаясь, нелестных характеристик самого этого термина, который для него был тождественен софистике. В самом же посвященном диалектике разделе философ фактически был занят анализом тех иллюзий, в которые впадает разум при отсутствии у него дисциплины, предписанной критикой. Напомню, что, по Канту, противоречия в разуме таят для него огромную опасность и могут привести, в конечном счете, к скептицизму, с которым философ всю жизнь неустанно боролся. Спасая целостность разума, Кант, в отличие от всех его последователей, пытался всячески преодолеть наличие в нем противоречивой двойственности. И если разум у него ни в коей мере не может мириться с возникшими в его недрах противоречиями (антиномиями), то, начиная с Фихте, именно противоречие становится не только источником и движущей силой развития Я, но и универсальным методом познания всего сущего. Сам же процесс познания превращается, по сути, в переход от одного противоречия к другому путем их обнаружения и разрешения.

Можно возразить, что идеи диалектики красной нитью проходят через всю немецкую классику, обогащаясь и принимая наиболее зрелую форму у Гегеля. Можно упомянуть и то, что в ряде ранних своих работ Гегель высоко отзывался о кантовских антиномиях и попытаться вывести преемственность в развитии диалектической теории и метода. Однако это не так: Гегель, действительно создавший наивысшую форму диалектики и диалектического метода, так и не принял кантовский способ устранения противоречий из разума и то решение антиномий, которое было предложено его предшественником. Диалектику Канта сегодня поэтому не следует смешивать с гегелев- ской или же с марксистской версией, трактуя ее как совершенно иную, хотя и не менее интересную и продуктивную форму диалектики.

Учитывая все выше отмеченное, оказывается весьма проблематичным говорить о единстве, цельности и «генеалогической преемственности» в развитии немецкой философии конца XVIII - первой трети XIX вв., а также о Канте как основоположнике классического идеализма Фихте, Шеллинга и Гегеля. Это, однако, вовсе не умаляет роль и значение великого кенигсбергского философа в истории как немецкой, так и западноевропейской философии в целом, наоборот, говорит об уникальности его учения, благодаря которому философия обрела дух основательности и критичности. Более того, это позволяет более скрупулезно и точно подходить к анализу историко-философского процесса, избавляться от десятилетиями наличествовавших в советские годы стереотипов и штампов, имевших, зачастую, в том числе и идеологически ангажированный характер. Речь идет, в том числе, и о пересмотре самой идентификационной метки, используемой для обозначения данной философской традиции, полагая в качестве более адекватного термина для ее характеристики - «Немецкий идеализм конца XVIII - первой трети XIX вв.» $[1 ; 2 ; 8]$. Но это уже тема другого исследования.

\section{Jumepamypa}

1. Быкова М.Ф. О философском проекте немецкого идеализма. Историко-философский ежегодник. 2012. № 2011. C. 242-267.

2. Быкова М.Ф. О характере немецкого идеализма конца XVIII - первой трети XIX вв. История философии: вызовы ХХІ века. Москва : Канон, 2014. С. 215-219.

3. История философии / Под ред. В.В. Васильева [и др.] Москва, 2005. 680 с.

4. Кант И. Заявление по поводу наукоучения Фихте. Трактаты и письла. Москва : Наука, 1980. С. 624-626.

5. Мотрошилова Н.В. Рождение и развитие философских идей: Историко-философские портреты. Москва . Политиздат, 1991. 464 с.

6. Панафидина О.Н. Трансцендентализм И. Канта и немецкий идеализм (К вопросу о некоторых стереотипах экспликации кантовской теоретической философии). Вопросы философии. 2011. № 4. С. 177-188.

7. Резвых П.В. В поисках нового образа немецкой классической философии. История философии: вызовы XXI века. Москва : Канон, 2014. С. 207-210.

8. Румянцева Т.Г. Немецкий идеализм: от Канта до Гегеля. Минск : Вышейшая школа, 2015. 271 с.

9. Фихте И. Г. Первое введение в наукоучение. Сочинения в двух томах. Том 1. Санкт-Петербург, 1993. C. $443-477$.

10.Шеллинг Ф.В.Й. Система трансцендентального идеализма. Сочинения в двух толах. Том 1. Москва : Мысль, 1987. С. 227-490.

11.Энгельс Ф. Людвиг Фейербах и конец классической немецкой философии. Маркс $K$., Энгельс Ф. Избранные произведения в двух толах. Т. ІІ. Москва, 1948. С. 339-382. 


\section{Анотація}

Руляниева T. Г. Про так звану «генеалогічну спадкоємність» у розвитку німецького классичного ідеалізму. - Стаття.

У статті аналізується відтворена в радянській історико-філософській та навчальній літературі схема про «генеалогічну наступність», цілісність та наявність іманентної логіки в розвитку німецької класичної філософії. При цьому вважалося, що всім представникам цієї інтелектуальної традиції властиве єдине проблемне поле, подібне розуміння системоутворювальних фундаментальних ідей і понять. Показано, що знайомство з новітніми науковими розробками та архівними даними останніх десятиліть істотно змінили образ німецької класики, що дає нам змогу стверджувати про надмірну спрощеність такого роду схеми, її неповну відповідність реальному стану справ, згідно з яким традиція німецького ідеалізму постає швидше «у строкатому різноманітті версій розгортання філософського дискурсу». У статті показана також ідеологічна ангажованість енгельсівського, так званого «сходового», тлумачення розвитку німецької класичної філософії, згідно з яким кожен наступний за Кантом її представник позиціонувався як такий, що перевершує за результатами свого попередника, а всі догегелівські системи розглядалися тільки як підготовка до створення спочатку гегелівської, а потім і марксистської філософіï. Гегель у цій схемі поставав як вінець всього німецького ідеалізму, а, відповідно, Маркс і Енгельс - як вершина всієї німецької філософської думки як такої. Автор висловлює думку про те, що нині досить проблематично стверджувати не лише про «генеалогічну наступність» у розвитку німецької класики, а й про місце I. Канта, як родоначальника подальших ідеалістичних систем I. Фіхте, Ф. Шеллінга та Г. Гегеля. Показано специфіку кантівської реформи метафізики, яка була радикально відкинута його послідовниками, починаючи вже з Фіхте, який здійснив їі переродження на діалектичній основі; розкрито також особливості розуміння Кантом діалектики, яку жодною мірою не слід змішувати з гегелівською або з марксистською їі версією. Це зовсім не применшує роль і значення великого кенігсберзького мислителя, а, навпаки, свідчить про унікальність його вчення, завдяки якому філософія набула духу грунтовності і критичності. Таким чином, ми можемо більш скрупульозно і точно підходити нині до аналізу історико-філософського процесу, позбавляючись багатьох радянських стереотипів і штампів, що мали, зокрема, ідеологічно ангажований характер.

Ключові слова: німецький ідеалізм, I. Кант, І.Г. Фіхте, Ф.В.Й. Шеллінг, Г.В.Ф. Гегель, традиційна схема розвитку німецької класики та їі новий образ, місце I. Канта в традиції німецького ідеалізму.

\section{Summary}

Rumyantseva T. G. On the so-called "genealogical continuity" in the development of German classical idealism. - Article.

The article analyzes the scheme reproduced in the Soviet historical, philosophical and educational literature about "genealogical continuity", integrity and the presence of inherent logic in the development of German classical philosophy. At the same time, it was believed that all representatives of this intellectual tradition have a single problem field, a similar understanding of systemic and fundamental ideas and concepts. It is shown that familiarity with the latest scientific developments and archival data of recent decades has largely changed the image of German classics, which allows us to argue about the excessive simplification of this kind of scheme, its incomplete compliance with the real state of affairs, according to which the tradition of German idealism appears more likely "in the first variety of competing versions of the deployment of philosophical discourse". The article also shows the ideological engagement of the Engels scheme for the development of German classical philosophy, according to which every representative following I. Kant was positioned as superior in the results of his predecessor, and all pre-Hegelian systems were considered only as preparations for the creation of Hegel's and then Marxist philosophy. The author conducts the idea that today it is quite problematic to assert not only about "genealogical continuity" in the development of German classics, but also about the place of I. Kant, as the ancestor of subsequent idealistic systems of I. Fichte, F. Schelling and G. Hegel. It is shown the specificity of the Kantian reform of metaphysics, which was radically rejected by his followers, starting with Fichte, who carried out its transformation on a dialectical basis; it is also revealed the peculiarities of Kant's understanding of dialectics, which in no way should be confused with the Hegelian or Marxist version. This does not diminish the role and significance of the great Konigsberg's thinker, but, rather, on the contrary, testifies to the uniqueness of his teachings, thanks to which philosophy has gained a spirit of thoroughness and criticality. This does not diminish the role and significance of the great Konigsberg's thinker, but, rather, on the contrary, testifies to the uniqueness of his teachings, thanks to which philosophy has gained a spirit of thoroughness and criticality. Thus, we can more scrupulously and accurately approach today the analysis of the historical and philosophical process, getting rid of many Soviet stereotypes and clich s, which among other things, had an ideologically biased character.

Key words: German idealism, Kant, Fichte, Shelling, Hegel, Traditional scheme of the development of German classic philosophy and its new image, place of Kant in the tradition of German idealism. 